\title{
The deformation mechanism of soft coal roadway under dynamic mining influence and its optimization support design
}

\author{
Z.G. $\mathrm{SUN}^{1} \&$ Y. GOU${ }^{1} \&$ J. YANG ${ }^{1} \& Z . W . B I^{2} \&$ S.G. $L I^{2}$ \\ ${ }^{1}$ China Coal Technology Engineering Group Chongqing Research Institute, Chongqing, China \\ ${ }^{2}$ Safety Branch, China Coal Research Institute, Beijing, China;
}

KEYWORD: Soft coal roadway; Dynamic mining pressure; Surrounding rock control; Optimization support

ABSTRACT: In light of the coal roadway deformation and breakage problems in soft rock conditions under dynamic pressure influence, based on coupled-supporting principle, combined theories and computer numerical simulation, the floor heave and spalling mechanism under the influence of multiple mining activities were analyzed and a rational pillar size was calculated and bolt-cable coupling improvement support projects were designed on the basis of the original support plan. The study result shows that it was expansion-flexural composite of floor heave and rib spalling affected by coal pillar size. It can effectively control the volume expansion at the roadway bottom plastic zone and reduce the impact of the surrounding rock pressure of two sides on the floor by increasing coal pillar size to $25 \mathrm{~m}$ and using "add floor rock bolt $\&$ increase support density in two sides of roadway \& enlarge anchor length" comprehensive reinforced support means.

\section{Introduction}

For a long time, the problem of soft rock roadway supporting is always one of the major technical hurdle which seriously influence the coal production safety in China coal mines ${ }^{[1-2]}$. Influenced by soft rock and engineering stress disturbed, there were large-scale rib spalling and floor heave issues during mining in No.3101 work face, and they are seriously restricting the safety production of coal mine (as shown in Figure.1). In allusion to the problems mentioned above, the deformation mechanism of soft coal roadway was analyzed and an improved roadway support design scheme was proposed by combining the theories and computer numerical simulation.

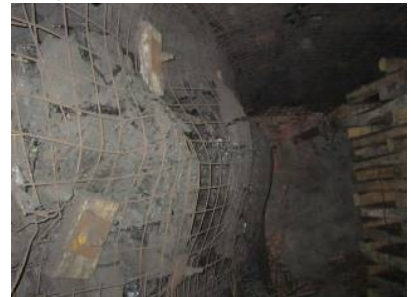

Rib spalling

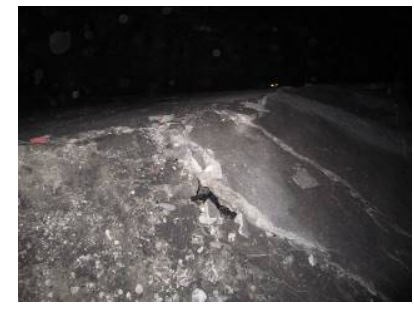

Floor heave

Figure 1. The destruction of coal roadway in No. 3101 working face of Chahasu coal mine

\section{Engineering general situation}

The No.3101 long-wall fully-mechanized working face with large mining height is the first mining face in Chahasu coal mine, its buried depth is $398.8 \mathrm{~m}$ and the thickness is $6.45 \mathrm{~m}$. Structures in zonation are simple and dip angle of coal seam is $1 \sim 3^{\circ}$. The roof rock was composed of mudstones, sandy-mudstones and medium grain sandstones. Among them, the medium grain sandstone is the main roof and its thickness is about $12.55 \sim 24.85 \mathrm{~m}$. The immediate floor of coal seam is carbon mudstone with a thickness of $0.85 \sim 1.8 \mathrm{~m}$, the main floor is consisted of coarse-grained sandstones and its thickness is $5.35-14.18 \mathrm{~m}$.

\section{Analyzing reasons of deformation in roadway}

\section{The reasons for floor heave}

According to the deformation behavior of coal roadway floor heave in No. 31 mining area, it can be determined that the floor heave mechanism is belong to swelling-flexing complex floor heave ${ }^{[1]}$; In 
accordance with the size of deformation of floor heave ${ }^{[3]}$, which can be attributed to the severe floor heave(amount of floor heave:300 500mm).

Based on the field investigation, one can draw a conclusion that the main reason of the phenomenon including ${ }^{[1,4-6]}$ :

(1) The roadway floor in No.31 mining area is made up of layers of mudstones, carbonaceous mudstones and the thin coal seams, and the swelling of rocks meeting with water lead to swelling heave;

(2) As the layer structural features of floor strata is striking, both sides of roadway would compress and load under the mining influence, on the one hand rock volume expansion and plastic destruction is aggravated, on the other hand roadway floor is affected by sliding surface effect and squeeze-film effect, resulting in flexing floor heave.

Principal stress distribution inside cross section of the roadway behind working face was simulated using FLAC ${ }^{3 \mathrm{D}}$ (as shown in Fig. 2), which shows there is shear slip damage at base angle under influence by strong mining-induced stress and there is plastic flow inside the roadway.

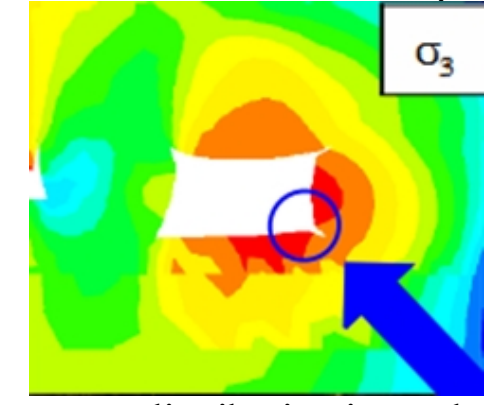

Figure 2. The stress distribution in roadway $\left(\right.$ FLAC $\left.^{3 \mathrm{D}}\right)$

(3) Due to inadequate stability of coal pillar, the damage width inside roadway coal side increased continuously caused by mining disturbance, which led to a lot of fissures and cracks at the surface of coal pillar and deep in it. Internal stress of surrounding rock of roadway was simulated using $\mathrm{PFC}^{2 \mathrm{D}}$ (as shown in Fig. 3), showing that the radius of plastic zone increased with the increase of expansion pressure due to creep and expansion of surrounding rock.

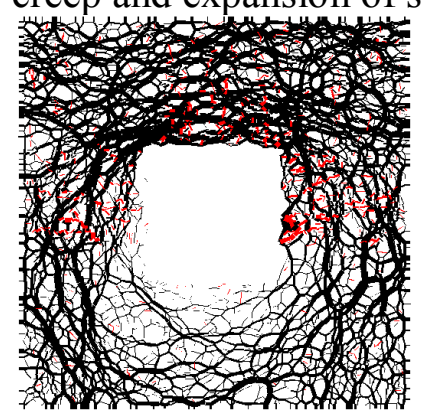

Figure 3. Internal stress-transfer of surrounding rock

\section{Rib spalling mechanism in coal roadway sides}

The pressure affects degree roadway is determined by the width of coal pillar ${ }^{[2]}$ : it can be divided into rupture zone, plastic zone and elastic zone in coal pillar, and generally speaking, stress concentration coefficient $(K)$ is $2 \sim 3$; when the size of coal pillar is smaller, the peak value of support pressure on the both sides of the edge will overlap together and the K-value could reach $4 \sim 5$ under the effect of mining, and then, the surface of coal pillar will be damaged seriously under influence of stresses concentrating .

According to above analysis, it can be conclude that the deformation of roadway surrounding rock under the influence of mining in No.31 mining area is mainly caused by the lithology of bottom and strength of coal pillar and the strength of coal pillar can be improved through optimizing coal pillar size and strengthening support. Literature [7-8] considers that anchor reinforcement can make the coal pillar in three-dimensional pressure and improve the stability and bearing capacity. Literature [9-10] thinks that it can reduce the tensile stress and the amount floor heave in the roadway floor rock by strengthening both sides of roadway.

However, none of the above literatures have studied multiple mining activities impact on the roadway. Therefore, under the tunnel had been formed and do not effect normal production premise, 
this article mainly discusses how to solve problem about roadway deformation and breakage in No.31 mining area through calculating the reasonable section pillar size and using supplement support methods.

\section{Coal pillar size Optimization}

\section{Design the coal pillar dimensions based on equilibrium theory}

Affected by the mining ${ }^{[2]}$, as is shown in figure 4, plastic deformation zone would be formed respectively on both sides of coal pillar $\left(\mathrm{x}_{0} \& \mathrm{x}_{1}\right)$, considering safety parameter, the reasonable virgin coal width $(B)$ can been obtained through the follow calculation formulas (see Formula1-3):

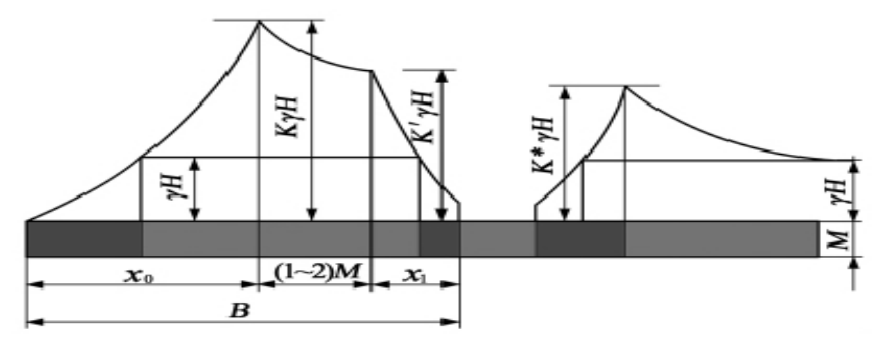

Figure 4. The internal stress distribution in coal pillar

$$
B \geq k \cdot\left(x_{0}+2 M+x_{1}\right)
$$

Where $k=$ safety factor, $1.15 \sim 1.45 ; x_{0}=$ plastic zone width of coal pillar in mining side, $\mathrm{m} ; x_{1}=$ the plastic zone width of coal pillar in non-mining side, $\mathrm{m}$.

$$
\begin{aligned}
& x_{0}=\frac{M}{2 f} \cdot \frac{1-\sin \varphi}{1+\sin \varphi} \cdot \ln \left(\frac{K \gamma H+C \cot \varphi}{\tau+C \cot \varphi} \cdot \frac{1-\sin \varphi}{1+\sin \varphi}\right) \\
& x_{1}=r_{0}\left\{\left[\frac{\gamma_{1} H \tan \varphi+C}{\tau \tan \varphi+C}(1-\sin \varphi)\right]^{\frac{1-\sin \varphi}{2 \sin \varphi}}-1\right\}
\end{aligned}
$$

where $M=$ coal mining height, $\mathrm{m} ; f=$ the friction coefficient among planes; $\varphi=$ the internal friction angle of coal, ${ }^{\circ} ; \tau=$ lateral force from supporting facilities to coal pillar, MPa; $C=$ cohesion between the coal seam and roof $\&$ floor, $\mathrm{MPa} ; K=$ the stress concentration factor, its can be given by formula 4; $\gamma=$ bulk density of coal, $\mathrm{kN} / \mathrm{m}^{3} ; H=$ the buried depth of coal seam, $\mathrm{m} ; \gamma_{1}$ - the average volume of rock masses, $\mathrm{kN} / \mathrm{m}^{3} ; r_{0}=$ the equivalent radius, $\mathrm{m} ; K=2.5$.

According to the actual simulation of working face in No.3101, the corresponding calculation parameters and results are shown in table 1.

\begin{tabular}{ccccccc} 
Table 1. & \multicolumn{1}{c}{ Parameter table of coal pillar size calculation } \\
\hline$M$ & $H$ & $K$ & $f$ & $\varphi$ & $C$ & $k$ \\
6.45 & 398.8 & 2.5 & 0.4 & $28^{\circ}$ & 2.0 & 1.3 \\
$\tau$ & $\gamma$ & $\gamma_{1}$ & $r_{0}$ & $x_{0}$ & $x_{1}$ & $B$ \\
0.1 & 25 & 35 & 4.3 & 2.66 & 2.35 & 23.28 \\
\hline
\end{tabular}

\section{Numerical simulation of coal pillar size}

The present coal pillar width is $18.6 \mathrm{~m}$, the numerical simulation studies between No.3101 belt convey roadway and 3103 ventilation roadway, the model size: $300 \mathrm{~m}$ long, $200 \mathrm{~m}$ wide and $50 \mathrm{~m}$ high, total 30240 block units and 33726 grid points. There are two kinds of simulation design, coal pillar size $18 \mathrm{~m}$ and $25 \mathrm{~m}$, study on the change rules of plastic zone and bearing stress under the influence of $1^{\text {st }}$ and $2^{\text {nd }}$ mining respectively.

\section{The change rules of plastic destroy region}

As the pillar width is $18 \mathrm{~m}$, the ranges of plastic zone in 3103 ventilation roadway and 3101 transportation roadway under the influence of mining activity are shown in Figures 5. Besides, when the pillar width is $25 \mathrm{~m}$, its appropriate ranges of plastic zone are shown in Figure 6 . And the statistical analysis of the results is shown in table 2 . 


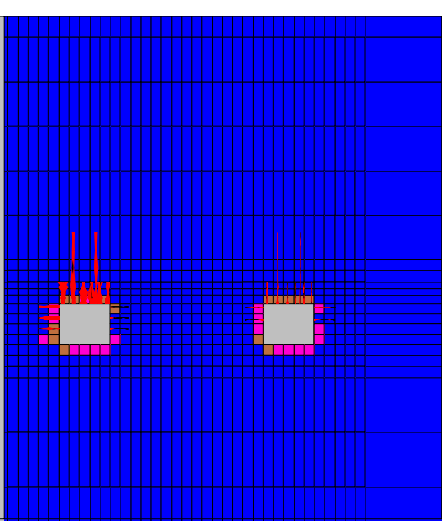

$1^{\text {st }}$ coal-mining influence

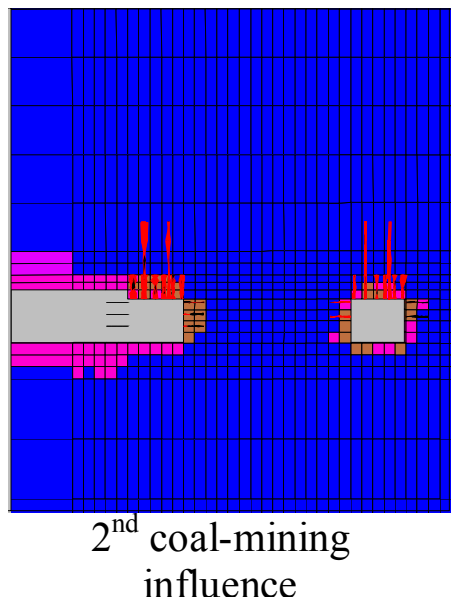

Figure 5. The regions of plastic zone when pillar width is $18 \mathrm{~m}$

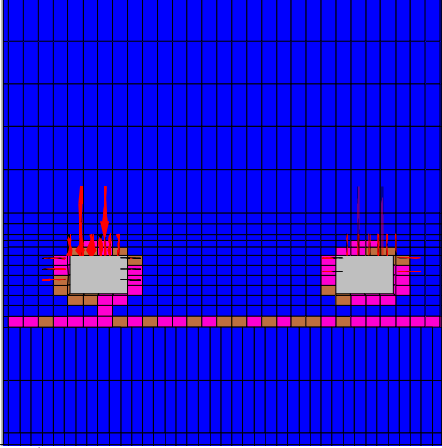

$1^{\text {st }}$ coal-mining influence

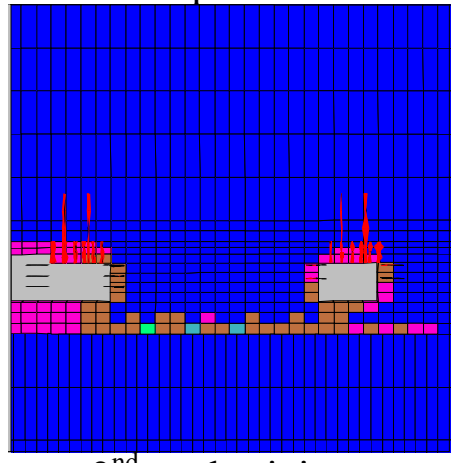

$2^{\text {nd }}$ coal-mining influence

Figure 6 . The regions of plastic zone when pillar width is $25 \mathrm{~m}$

Table 2. The st atistical table of plastic destroy region with $18 \mathrm{~m}$ and $25 \mathrm{~m}$ pillar width

\begin{tabular}{|c|c|c|c|c|}
\hline $\begin{array}{l}\text { Pillar } \\
\text { Width }\end{array}$ & $\begin{array}{l}\text { Mining } \\
\text { Order }\end{array}$ & & $\begin{array}{l}\text { Roadway } \\
\text { Position }\end{array}$ & $\begin{array}{c}\text { Plastic } \\
\text { Zones/m }\end{array}$ \\
\hline \multirow{4}{*}{$18 \mathrm{~m}$} & \multirow[b]{2}{*}{$1^{\text {st }}$} & \multirow{2}{*}{$\mathrm{r}$} & 3101BV- & 0.9 \\
\hline & & & $\begin{array}{l}3103 \mathrm{~V}-\mathrm{r} \\
3103 \mathrm{~V}-1\end{array}$ & $\begin{array}{l}0.8 \\
0.8\end{array}$ \\
\hline & \multirow[b]{2}{*}{$2^{\text {nd }}$} & \multirow[b]{2}{*}{$r$} & $3101 \mathrm{BV}-$ & 20 \\
\hline & & & $\begin{array}{l}3103 \mathrm{~V}-\mathrm{r} \\
3103 \mathrm{~V}-1\end{array}$ & $\begin{array}{l}2.0 \\
2.0\end{array}$ \\
\hline \multirow{4}{*}{$25 \mathrm{~m}$} & \multirow{2}{*}{$1^{\text {st }}$} & \multirow{2}{*}{$\mathrm{r}$} & $3101 \mathrm{BV}-$ & 0.8 \\
\hline & & & $3103 \mathrm{~V}-\mathrm{r}$ & 0.8 \\
\hline & \multirow[b]{2}{*}{$2^{\text {nd }}$} & \multirow[b]{2}{*}{$r$} & $3101 \mathrm{BV}-$ & 00 \\
\hline & & & $\begin{array}{l}3103 \mathrm{~V}-\mathrm{r} \\
3103 \mathrm{~V}-1\end{array}$ & $\begin{array}{l}1.0 \\
1.0\end{array}$ \\
\hline
\end{tabular}

* $\mathrm{BC}=$ belt convey roadway; $1=$ left side;

$\mathrm{V}=$ ventilation roadway; $\mathrm{r}=$ right side.

According to table 2, it has been determined that the plasticity ranges of side coal-walls would decrease obviously and the floor plastic region would extend to deep site with the increase of the coal pillar width. The ranges of plastic zones of the two size coal pillar have little difference under the first mining influence, while, under the second mining influence, the ranges of plastic zones of $18 \mathrm{~m}$ coal pillar significantly larger than $25 \mathrm{~m}$.

\section{The distribution rules of surrounding rock}

The distribution characteristics of vertical stress in 3101 working face under the influence of mining activity when pillar width is $18 \mathrm{~m}$ are shown in Figures 7 . Besides, when the pillar width is $25 \mathrm{~m}$, its 
vertical stress distributions are shown in Figure 8. And the statistical analyses of the results are shown in table 3.

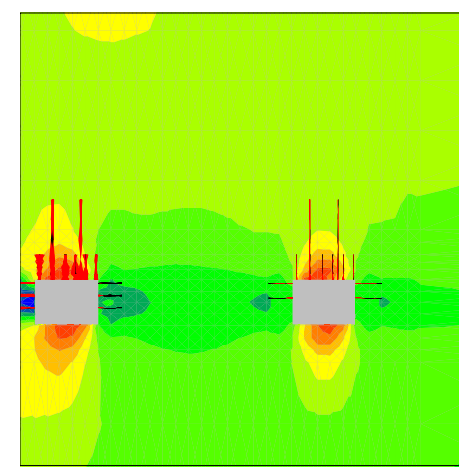

$1^{\text {st }}$ coal-mining influence

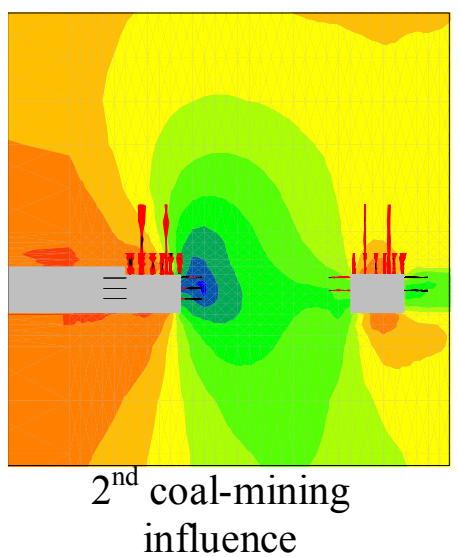

Figure 7. The vertical stress distribution diagram when pillar width is $18 \mathrm{~m}$

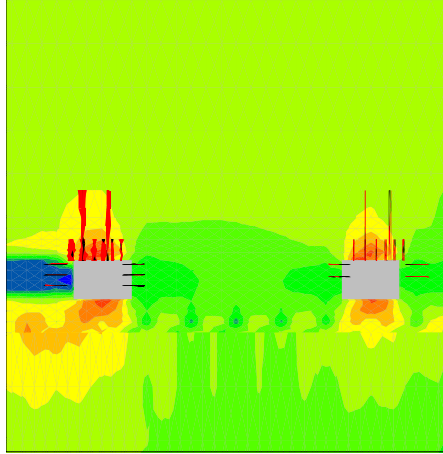

$1^{\text {st }}$ coal-mining influence

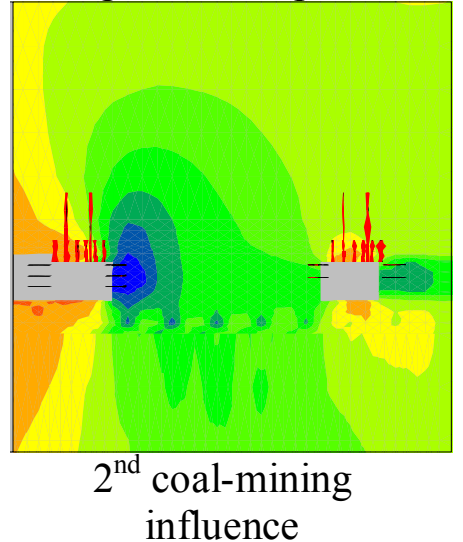

Figure 8 . The vertical stress distribution diagram when pillar width is $25 \mathrm{~m}$

Table 3. The statistical table of vertical stress distribution with $18 \mathrm{~m}$ and $25 \mathrm{~m}$ pillar width

\begin{tabular}{ccccc}
\hline $\begin{array}{c}\text { Pillar } \\
\text { Width }\end{array}$ & $\begin{array}{c}\text { Minin } \\
\text { O } \\
\text { Order }\end{array}$ & $\begin{array}{c}\text { Roadway } \\
\text { Position }\end{array}$ & $\begin{array}{c}\text { Peak- } \\
\text { Point } \\
\text { Position/ } \\
\text { m }\end{array}$ & $\begin{array}{c}\text { Peak- } \\
\text { Point } \\
\text { size/MPa }\end{array}$ \\
\hline \multirow{4}{*}{$18 \mathrm{~m}$} & $1^{\text {st }}$ & $3101 \mathrm{BC}-1$ & 0.5 & 4.99 \\
& & $3103 \mathrm{~V}-1$ & 2.0 & 4.00 \\
& $2^{\text {nd }}$ & $3103 \mathrm{~V}-\mathrm{r}$ & 1.0 & 4.00 \\
& & $3101 \mathrm{BV}-\mathrm{r}$ & 0.5 & 8.99 \\
\hline \multirow{3}{*}{$25 \mathrm{~m}$} & $1^{\text {st }}$ & $3101 \mathrm{BV}-1$ & 0.4 & 4.65 \\
& $2^{\text {nd }}$ & $3101 \mathrm{BV}-\mathrm{r}$ & 2.0 & 4.50 \\
& & $3101 \mathrm{BV}-\mathrm{r}$ & 1.8 & 8.05 \\
\hline
\end{tabular}

According to the stress analysis, as coal pillar's width increasing, the peak value and concentration factor of stress are slightly reduced, and local stress concentration shift towards shallow coal pillar and deep floor, the degree and range of stress concentration in roadway floor significantly reduce. There is obvious stress superposition phenomenon in $18 \mathrm{~m}$ coal pillar and no in $25 \mathrm{~m}$.

The results obtained from theories calculation and computer numerical simulation provide that the reasonable coal pillar width is $25 \mathrm{~m}$, and it can help reduce rib spalling and stress concentration in roadway floor by enlarging coal pillar width.

\section{Supporting parameters optimization}

Synthesizing the above theories and computer numerical simulation results, four kinds of supporting schemes centered on increasing strength of two side coal-walls support and decreasing cover rock pressure delivery to floor were put forward: (1)add base angle bolts; (2) increase density of two side coal-walls support; (3)add base angle bolts $\&$ increase density of two side coal-walls support; (4)add base angle bolts \& increase density of two side coal-walls support \& increase the 
bolts to have additional $1 \mathrm{~m}$ longer. Besides, install "welded steel fabric \& W-section wide steel strap" on the surface of roadway can control rib spalling and enhances the supporting force of the coal pillar effectively.

In order to compare the influence extent of different plans on rib spalling and floor heave, the original and four kinds of improvement support designs were simulated and analyzed. As is shown in the change curves of roof-to-floor convergence (see Figure 9), effect of plan four is the most obvious, the convergence of roof-to-floor is twenty-five percent lower. According to observe contour displacement comparison chart of support effects between plan four and original support methods of mine (see Figure 10), thus it can be seen that the deformations of roadsides and floor heave are effectively decreased (Floor maximum deflection decrease 41.67\%; Side-wall maximum deflection decrease $64.74 \%$ ).

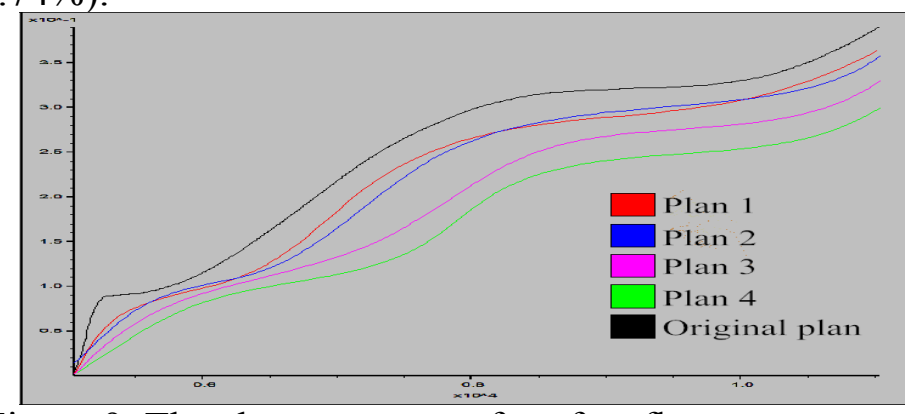

Figure 9. The change curves of roof-to-floor convergence

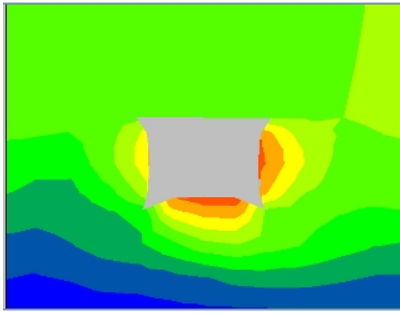

Original plan

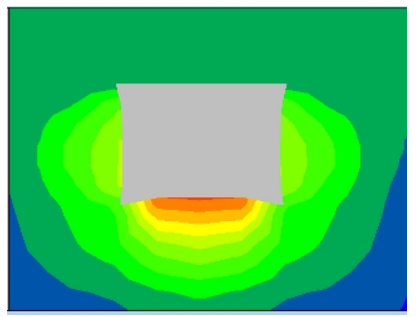

Plan four

Figure 10. The contour displacement comparison chart of support effects between plan four and original support methods

The field application effect as shown in Figure 11:
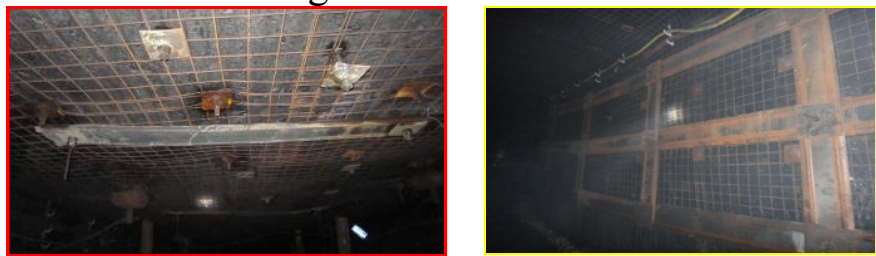

Figure 11. The effect of field application

\section{Conclusion}

1. The floor heave in No.31 mining area results from the integrated effect of soft rock swelling, sliding surface effect and squeeze-film effect, it belongs to swelling-flexing complex floor heave. Spalling problems on the surface of coal pillar due to insufficient pillar width.

2. As coal pillar's width increasing, the peak value and concentration factor of stress are slightly reduced, and local stress concentration shift towards shallow coal pillar and deep floor, the degree and range of stress concentration in roadway floor significantly reduce.

3. The ranges of plastic zones of the two size coal pillar have little difference under the first mining influence, but there is obvious stress superposition phenomenon in $18 \mathrm{~m}$ coal pillar. Under the second mining influence, the ranges of plastic zones of $18 \mathrm{~m}$ coal pillar significantly larger than $25 \mathrm{~m}$.

4. The results obtained from theories calculation and computer numerical simulation provide that the reasonable coal pillar width in No.31 mining area is $25 \mathrm{~m}$, and it can help reduce rib spalling and stress concentration in roadway floor by enlarging pillar width. 
5. By using "add base angle bolts $\&$ increase density of two side coal-walls support $\&$ increase the bolts' length" methods can control the deformation and breakage of the coal pillar effectively.

\section{References}

[1] He M.C. \& Sun X.M. 2004. China's coal mines soft rock engineering supporting design and construction guide. Beijing: Science Press.

[2] Qian M.G. \& Shi P.W. 2003. Mining pressure and strata control. Xuzhou: China Mining University Press.

[3] Xue S.X. et al. 2002. The soft rock tunnel supporting technology guide. Beijing: China Coal Industry Press.

[4] Liu L.M. \& Yang L. 2007. Experimental study on the technology of floor heave control in compact and fractured soft-rock roadway. Journal of Hunan University of Science\&Technology (Natural Science Edition) 22(2):13-17.

[5] Li S.Q \& Feng T. 2005. Study on mechanism and control of soft rock roadway floor heave in Gequan coal mine. Chinese Journal of Rock Mechanics and Engineering 24(8):1450-1456.

[6] Wang W.J. \& Hou C.J. 2003. New development of mechanism and control technique study of extraction opening floor heave. J.XIANGTAN MIN.INST 18(1):1-6.

[7] Duan S.W. 2009. Reinforcement mechanism of anchored bolt for coal pillar and analysis of influence factors of pillar strength. Coal Mining Technology14(3):62-64.

[8] Kang J.Z. et al. The influence of roadway two sides strength on floor heave control. Safety in Coal Mines (7):179-182.

[9] Wang W.J. \& Feng T. Study on mechanism of reinforcing sides to control floor heave of extraction opening. Chinese Journal of Rock Mechanics and Engineering 24(5): 808- 811.

[10] ZHANG Hua, SUN Zhong-guang, LI Shao-gang, et al. Surrounding Rock Deformation Mechanism and Control Technology of Soft Coal Roadway at Fully Mechanized Working Face[J]. Safety in Coal Mines, 2015, 46(3):234-236. 